\title{
Residual Effect of Biochar on Soil Properties and Yield of Maize (Zea mays L.) under Different Cropping Systems
}

\author{
Sara, Z. Shah, T. Shah \\ Department of Soil and Environmental Sciences, Faculty of Crop Production Sciences, the University of Agriculture, \\ Peshawar, Pakistan \\ Email: Sarakhanses@gmail.com
}

How to cite this paper: Sara, Shah, Z. and Shah, T. (2018) Residual Effect of Biochar on Soil Properties and Yield of Maize (Zea mays L.) under Different Cropping Systems. Open Journal of Soil Science, 8, 16-35.

https://doi.org/10.4236/ojss.2018.81002

Received: October 19, 2017

Accepted: January 8, 2018

Published: January 11, 2018

Copyright $\odot 2018$ by authors and Scientific Research Publishing Inc. This work is licensed under the Creative Commons Attribution International License (CC BY 4.0). http://creativecommons.org/licenses/by/4.0/

\begin{abstract}
A field experiment was conducted to examine the residual influence of biochar applied previously to an established experiment at the Agriculture University Research Farm, Peshawar on soil properties and yield of maize crop during summer 2016. The experiment was established in RCB design with split plot arrangements having cropping systems (CS) in main plots and biochar (BC) in sub-plots. Cropping systems were: 1) wheat-mung bean; 2) wheat-maize; 3) chickpea-maize; and 4) chickpea-mung bean. During the past three seasons, each cropping system received biochar at $0,40,60$ and $80 \mathrm{t} \cdot \mathrm{ha}^{-1}$ along with recommended dose of NPK in each season. For this study, maize was planted after chickpea and wheat in summer 2016. The results showed that grain yield, cobs weight and total $\mathrm{N}$ uptake of maize was significantly greater for chickpea-maize than for wheat-maize cropping system. Soil organic $\mathrm{C}$ was also significantly higher in soil under chickpea-maize than under wheat-maize cropping system. However, other yield components such as stover yield, harvest index and $\mathrm{N}$ concentration in grain and stover of maize and soil properties such as $\mathrm{pH}, \mathrm{EC}$ and mineral $\mathrm{N}$ were non-significantly affected by cropping systems. With respect to residual effect of biochar grain yield of maize and bulk density of soil were maximum for treatment receiving biochar at $40 \mathrm{t} \cdot \mathrm{ha}^{-1}$ whereas cobs weight soil $\mathrm{pH}$ and mineral $\mathrm{N}$ were highest receiving biochar at $60 \mathrm{t} \cdot \mathrm{ha}^{-1}$. Moreover, $\mathrm{N}$ concentration in stover, $\mathrm{N}$ uptake and soil organic $\mathrm{C}$ were maximum for treatment receiving biochar at $80 \mathrm{t} \cdot \mathrm{ha} \mathrm{a}^{-1}$. However, stover yield, harvest index, $\mathrm{N}$ concentration in grain, and soil EC were non-significantly affected by biochar treatments. However interactions between CS $\times$ BC were significant for yield and yield parameters of maize and for soil properties (bulk density mineral $\mathrm{N}$ ), while non-significant for harvest index, soil organic $\mathrm{C}, \mathrm{pH}$ and EC. It was concluded that chickpea-maize crop-
\end{abstract}


ping system performed better in terms of improving yield and yield components of maize and in improving soil properties. Application of biochar to previous crops also improved yield and yield parameters of the following maize as well as soil properties. Thus we recommend that legumes must be involved in cropping system for sustainable and higher productivity and improved soil properties. However, further studies are suggested to find out suitable dose of biochar for sustainable and economic crop productivity and soil fertility.

\section{Keywords}

Biochar, Residual Effect, Soil Properties, Cropping Systems, Yield and Yield Components of Maize

\section{Introduction}

Maize (Zea mays $L$.) is a versatile as well as complete cereal crop proving food for human being and feed for animals as well as different raw materials for industries [1]. After wheat and rice, maize is the $3^{\text {rd }}$ important cereal crop in Pakistan. In Khyber Pakhtunkhwa, maize is the $2^{\text {nd }}$ important cereal crop after wheat [2]. The area under maize in Pakistan is $1.1 \mathrm{~m}$ ha with a total production of 4.5 million metric tons [3] whereas Khyber Pakhtunkhwa contributes 56 percent to the total area and 63 percent to the total production of maize. The average potential yield of maize is greater than our average national yield. A number of factors are responsible for low production of maize in Pakistan. One of most important limiting factor is soil's low fertility. One way of increasing soil fertility on sustainable basis is the use of biochar.

Biochar is rich in organic carbon and resistant to microbial degradation. Biochar is produced from pyrolysis of different organic wastes. Quality of soil, nutrient cycling and sequestration of carbon through biochar application to agricultural land has received rising consideration. [4] suggested that the application of biochar is very important for the improvement of degraded soil. Application of biochar improves soil physical properties such as bulk density, water holding capacity, permeability, chemical properties such as nutrients availability, cation exchange capacity and retention, and biological properties such as microbial population, microbial biomass and microbial activities, thus ultimately increased crop yield [4] [5] [6]. The net influence of biochar on the physical characteristics of the soil depends on the interaction of the biochar by way of the physico-chemical properties of the soil as well as other determinant factor such as the climatic conditions and appliance of biochar management. [7] noticed the effect of biochar on regulation and production role of the agricultural soil. Positive effects of biochar on the plant-available phosphorus have been reported in other studies [8] [9]. Almost 50\% - 100\% of maize characteristics yield and water use efficiency was improved when use of biochar was enhanced since 15 to $20 \mathrm{t} \cdot \mathrm{ha}^{-1}$ 
[10]. Rate of crop development and uptake of nutrients was higher with increased levels of biochar [6].

Positive responses of yield and yield parameters of maize to biochar as soil amendment have been obtained/reported and the positive responses were mainly attributed to improvement in saturated hydraulic conductivity of the sandy soil, the same as a result throughout the growing season nutrients availability, moisture content and WUE were increased [9]. Soils amended with biochar resulted in improved in better crop establishment and definitely improved rate of crop development and net incorporation rate, and resulted in high production of corn [10]. By the application of biochar soil microbial life increases and thus enhanced carbon storage in soil thus reduced the used of synthetic fertilizers. [11] found that $\mathrm{N}$ losses could be restricted through biochar application because it retains nitrogen, increases cation exchange capacity and reduces nitrous oxide emissions. Increased in cation exchange capacity and soil $\mathrm{pH}$ have been noticed by the application of biochar. Application of biochar improved the overall sorption capacity of soils and consequently it may persuade the transport, and fate of dissimilar heavy metals and toxicity in the soil. [5] also reported the increased accessibility of most important plant nutrients due to biochar application. Although positive impact of biochar amendment on soil properties and crops yields has been reported, the information on sustainability of biochar impact is still sparse. This study was therefore undertaken to examine the impact of biochar applied to other crops in previous seasons on current maize and soil properties.

Therefore, present study was designed to examine the residual influence of biochar on yield of maize (Zea mays L.) as well as on selected soil properties under different cropping systems with the objective to assess the residual influence of biochar on bulk density, $\mathrm{pH}, \mathrm{EC}$, organic $\mathrm{C}$ of soil and as well as yield components of maize crop under continuous cereal or cereal-legume cropping systems.

\section{Materials and Methods}

Study was carried out to examine the residual influence of biochar on yield of maize and important properties of soil in a rotation experiment involving cereals and legumes. A rotation experiment was established at the research farm of Agriculture University, Peshawar during Rabi season 2014 involving cereal-cereal and cereal-legume cropping systems receiving different levels of biochar. The cropping systems were continuous cereals both in winter and summer (wheat-maize), cereal in winter (wheat) followed by legume (mung bean) in summer legume in winter (chickpea) followed by cereal in summer (maize) and continuous legumes both in summer and winter (chickpea-mung bean). The biochar treatments were 0,20 and $40 \mathrm{t} \cdot \mathrm{ha}^{-1}$ applied both to cereal and legume in each season as per plan presented in Table 1. The experimental design was RCB with split plot arrangement. Cropping systems were in main plots and biochar in sub-plots with four replications. Before the commencement of this study, 
Table 1. Detail of the crops receiving different levels of biochar in various seasons.

\begin{tabular}{|c|c|c|c|c|c|c|c|c|}
\hline \multicolumn{2}{|c|}{ Rabi season $2014 / 15$} & \multicolumn{2}{|c|}{$\begin{array}{c}\text { Kharif season } \\
2015\end{array}$} & \multicolumn{2}{|c|}{ Rabi season $2015 / 16$} & \multicolumn{2}{|c|}{$\begin{array}{c}\text { Kharif season } \\
2016\end{array}$} & \multirow{2}{*}{$\begin{array}{c}\begin{array}{c}\text { Amount of } \\
\text { biochar }\end{array} \\
\text { applied from } \\
2014 \text { to } 2016 \\
\left(\mathrm{t} \cdot \mathrm{ha}^{-1}\right)\end{array}$} \\
\hline Crop & $\begin{array}{c}\text { Biochar } \\
\left(\mathrm{t} \cdot \mathrm{ha}^{-1}\right)\end{array}$ & Crop & $\begin{array}{l}\text { Biochar } \\
\left(\mathrm{t} \cdot \mathrm{ha}^{-1}\right)\end{array}$ & Crop & $\begin{array}{c}\text { Biochar } \\
\left(\mathrm{t} \cdot \mathrm{ha}^{-1}\right)\end{array}$ & Crop & $\begin{array}{l}\text { Biochar } \\
\left(\mathrm{t} \cdot \mathrm{ha}^{-1}\right)\end{array}$ & \\
\hline \multirow[t]{4}{*}{ Wheat } & 0 & Maize & 0 & Wheat & 0 & Maize & 0 & 0 \\
\hline & 20 & & 20 & & 20 & & 0 & 60 \\
\hline & 40 & & 0 & & 40 & & 0 & 80 \\
\hline & 0 & & 40 & & 0 & & 0 & 40 \\
\hline \multirow[t]{4}{*}{ Wheat } & 0 & Mung & 0 & Wheat & 0 & Mung & 0 & 0 \\
\hline & 20 & & 20 & & 20 & & 0 & 60 \\
\hline & 40 & & 0 & & 40 & & 0 & 80 \\
\hline & 0 & & 40 & & 0 & & 0 & 40 \\
\hline \multirow[t]{4}{*}{ Chickpea } & 0 & Maize & 0 & Chickpea & 0 & Maize & 0 & 0 \\
\hline & 20 & & 20 & & 20 & & 0 & 60 \\
\hline & 40 & & 0 & & 40 & & 0 & 80 \\
\hline & 0 & & 40 & & 0 & & 0 & 40 \\
\hline \multirow[t]{4}{*}{ Chickpea } & 0 & Mung & 0 & Chickpea & 0 & Mung & 0 & 0 \\
\hline & 20 & & 20 & & 20 & & 0 & 60 \\
\hline & 40 & & 0 & & 40 & & 0 & 80 \\
\hline & 0 & & 40 & & 0 & & 0 & 40 \\
\hline
\end{tabular}

biochar received by different treatments in each cropping systems were $0,40,60$ and $80 \mathrm{t} \cdot \mathrm{ha}^{-1}$.

For this study the field was thoroughly prepared after the removal of winter crops (wheat and chickpea). After the harvest of wheat and chickpea soil samples at $0-15 \mathrm{~cm}$ depth were collected from each treatment plot for the required analysis. After proper land preparation and soil sampling maize was planted in designated treatment plots. The row to row distance was kept $75 \mathrm{~cm}$ as well as plant to plant distance $30 \mathrm{~cm}$. Basal doses of $\mathrm{N}$ at $150 \mathrm{~kg} \cdot \mathrm{N} \cdot \mathrm{ha}^{-1} \mathrm{P}$ at 90 $\mathrm{kg} \cdot \mathrm{P}_{2} \mathrm{O}_{5} \cdot \mathrm{ha}^{-1}$ and $\mathrm{K}$ at $60 \mathrm{~kg} \cdot \mathrm{K}_{2} \mathrm{O} \cdot \mathrm{ha}^{-1}$ were apply in the form of urea, SSP and MOP respectively to each treatment plot. Nitrogen was apply in two splits half at sowing time and half at knee high stage of the crop, whereas all phosphorus as well as potassium were apply at the time of sowing. Weed was controlled manually. Similarly, the crop was irrigated when needed. All other recommended cultural practices should be followed throughout the growing season. Data were analyzed statistically according to [12] and means were compared using LSD test $(\mathrm{P} \leq 0.05)$ using statistical packages statistic 8.1 Agronomic data was recorded for some parameters like plant population, number of cob per plant, cob weight, grain yield, Stover yield and harvest index. 


\section{Laboratory Analysis}

\subsection{Soil Bulk Density}

The bulk density of soil was determined using core method [13]. In this procedure, pre-weighed soil cores of known dimensions were carefully inserted in each treatment plot at proper water soil conditions. The cores were carefully removed and then transported to lab. After weighing, cores were dried in oven at $105^{\circ} \mathrm{C}$ for $24 \mathrm{hr}$. The cores were then removed from oven and cooled in desecrator and re-weighed to determine weight of dry sample accommodated in the core. The volume of core was taken as volume of the soil and bulk density was calculated using the expression

$$
B D=\frac{\text { Mass of soil }}{\text { Vol of soil }} .
$$

\subsection{Organic Matter Content}

Soil organic matter content was determined using method of [14]. Briefly soil sample $(1.0 \mathrm{~g})$ was treated with $\mathrm{K}_{2} \mathrm{Cr}_{2} \mathrm{O}_{7}$ solution $(10 \mathrm{ml}$ of $1.0 \mathrm{~N})$ and concentrated sulphuric acid $(20 \mathrm{ml})$. After adding distilled water $(200 \mathrm{ml})$ the suspension was filtered and the filtrate was titrated against ferrous sulphate solution $(0.5 \mathrm{~N})$ in the presence of organophneonpthaline as indicator. A blank sample also runs simultaneously.

\subsection{Determination of Mineral N in Soil}

Total mineral $\mathrm{N}$ in soil was determined by the steam distillation method of [15]. In this procedure, twenty g soil samples was taken in shaking bottle as well as $200 \mathrm{ml}$ of $1 \mathrm{M} \mathrm{KCl}$ was added to it. The sample was then kept on a horizontal shaker and shaken for 1 hour. After shaking, the sample was then filtered through Whatman-42 filter paper. Then twenty $\mathrm{ml}$ extract was distilled with $\mathrm{MgO}$ and devarda's alloy to recover both ammonium and nitrate into $5 \mathrm{ml}$ boric acid mixed indicator solution. The distillate was titrated against $0.005 \mathrm{M} \mathrm{HCl}$.

\subsection{Soil pH and ECe}

For determination of soil $\mathrm{pH}$ and ECe $10 \mathrm{~g}$ soil sample was taken in a conical flask and $50 \mathrm{ml}$ distilled water was added to make soil water suspension of 1:5. The suspension was shaken for 30 minutes on mechanical shaker and $\mathrm{pH}$ of the suspension was measured on pH meter [16] and EC on EC meter (Jenway 4510).

\subsection{Total Nitrogen}

Total $\mathrm{N}$ in soil and plant sample was determined using of the Kjeldhal method [17]. In this method, $0.2 \mathrm{~g}$ soil or plant finely ground samples were taken in a digestion tube. Then digestion mixture $(1.1 \mathrm{~g})$ and concentrated sulfuric acid (3 $\mathrm{ml}$ ) were added to it and digested at $350^{\circ} \mathrm{C}$ on a digestion block till greenish color appeared. The samples were removed from the digestion block and allowed to cool for now and again. The digest was diluted to $100 \mathrm{ml}$ with distilled water. For 
distillation, $20 \mathrm{ml}$ of the digest was taken in a distillation flask together with $4 \mathrm{ml}$ of $40 \% \mathrm{NaOH}$ and distilled in to boric acid mix indicator solution. The distillate was titrated against $0.005 \mathrm{~N} \mathrm{HCl}$.

The total nitrogen in sample was calculated as follows:

$$
\text { Total nitrogen }(\%)=\frac{(\text { Sample }- \text { Blank }) \times 0.005 \times 0.014 \times 100 \times 100 \mathrm{~s}}{\text { Wt. of soil } \times 20} .
$$

\subsection{Total N Uptake in Plant (kg·ha-1)}

Nitrogen concentration in stover and grains was determined and converted to $\mathrm{kg}$ $\mathrm{N} \cdot \mathrm{ha}^{-1}$ using the stover and grain yields in $\mathrm{kg} \cdot \mathrm{ha}^{-1}$. Total uptake was calculated as follows:

Total $\mathrm{N}$ uptake $\left(\mathrm{kg} \cdot \mathrm{ha}^{-1}\right)=$ Total $\mathrm{N}$ in grains + Total $\mathrm{N}$ in stover $\left(\mathrm{kg} \cdot \mathrm{ha}^{-1}\right)$.

\section{Results and Discussion}

\subsection{Plant Population}

The data showed that plant population was not significantly affected by cropping systems $(\mathrm{CS})$, biochar $(\mathrm{BC})$ levels and by their interaction $(\mathrm{CS} \times \mathrm{BC})($ Table 2$)$. Although the effect of cropping system was not significant yet maximum number of plants $\left(63,512 \mathrm{ha}^{-1}\right)$ was obtained for chickpea/maize cropping system which was statistically similar to wheat/maize cropping system. Similarly, the differences between the biochar and control treatments were non-significant. However, the maximum plant numbers of $65,714 \mathrm{ha}^{-1}$ was noticed with the application of $80 \mathrm{t} \cdot \mathrm{ha}^{-1}$ biochar which was statistically similar to other treatments. The increase in plant population in biochar treatments suggests the carry over effect of biochar. [18] reported that application of biochar removed all the constrains that limiting the plant growth as well as also enhanced the fertilizers use efficiency as well as hence increased plant biomass. [9] also report that biochar application improved nitrogen availability in soil and transport in plant so more photosynthesis were formed and plant biomass were increased. However, [19] observed that biochar, FYM and mineral nitrogen did not cause any significant variation in maize plant population at harvest although maximum plant population at harvest were recorded in plots where only biochar or biochar plus FYM were applied.

\subsection{Number of Cobs}

Data revealed that number of cobs in maize was significantly affected by cropping system (CS), biochar (BC) levels and by their interaction (Table 2). Significantly greater numbers of cobs $\left(60446 \mathrm{ha}^{-1}\right)$ were observed for treatment having chickpea than wheat in the preceding season suggesting the carry over effect of chickpea on the following maize crop (Figure 1). Significantly greater numbers of cobs were obtained for treatment receiving biochar in the previous season compare with the control treatment. It was observed that the maximum 
Table 2. Plant population, number of cobs and cobs weight $\left(\mathrm{kg} \cdot \mathrm{ha}^{-1}\right)$ of maize as affected by cropping systems and previous application biochar.

\begin{tabular}{cccc}
\hline Cropping system $(\mathrm{CS})$ & Plant population & Number of cobs & Cobs weight \\
\hline Wheat-maize & 61,726 & $54,780 \mathrm{~b}$ & $5863 \mathrm{~b}$ \\
Chickpea-maize & 63,512 & $60,446 \mathrm{a}$ & $7524 \mathrm{a}$ \\
Significance $(\mathrm{p} \leq 0.05)$ & $\mathrm{NS}$ & $*$ & $*$ \\
Biochar $(\mathrm{BC})\left(\mathrm{t} \cdot \mathrm{ha}^{-1}\right)$ & & & $5881 \mathrm{~b}$ \\
0 & 58,095 & $51,941 \mathrm{~b}$ & $6762 \mathrm{ab}$ \\
40 & 63,572 & $60,238 \mathrm{ab}$ & $7250 \mathrm{a}$ \\
60 & 63,095 & $57,024 \mathrm{ab}$ & $6881 \mathrm{ab}$ \\
80 & 65,714 & $61,250 \mathrm{a}$ & 1223 \\
LSD $(\mathrm{P} \leq 0.05)$ & NS & 8848 & \\
Interaction & & & $* *$ \\
CS $\times$ BC & NS & $*$ & \\
\hline
\end{tabular}

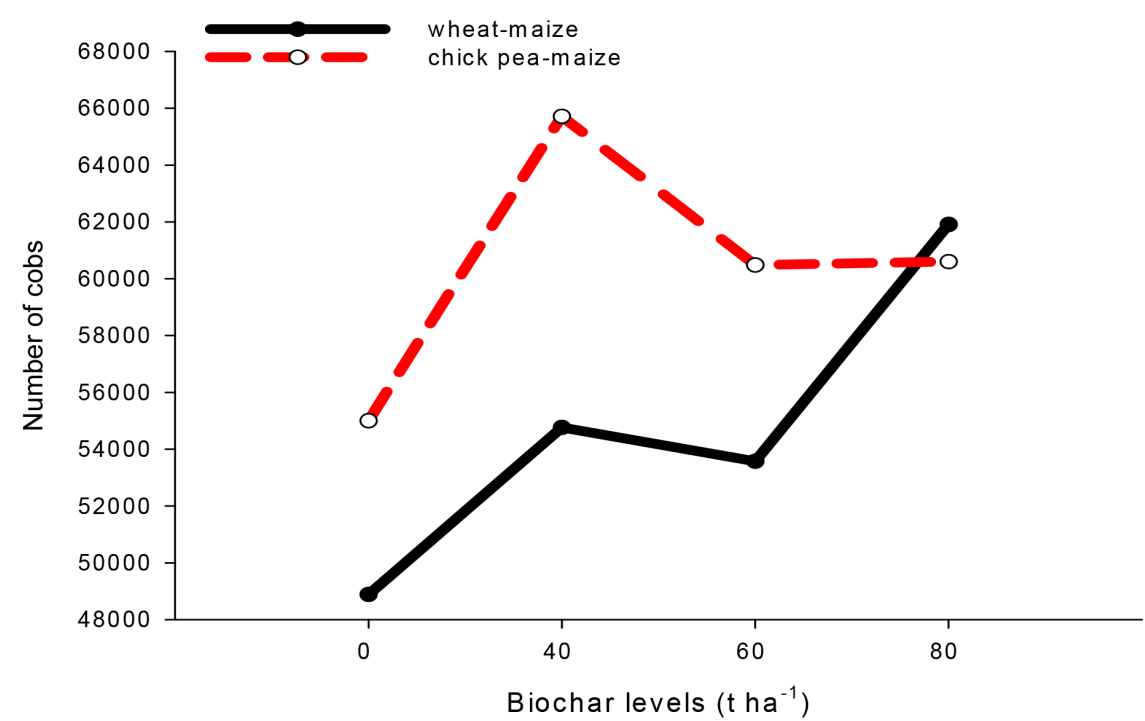

Figure 1. The influence of cropping systems and biochar interaction on number of cobs of maize.

numbers of cobs $\left(61,250 \mathrm{ha}^{-1}\right)$ were obtained for treatment receiving biochar at $80 \mathrm{t} \cdot \mathrm{ha}^{-1}$ but this be statistically alike to the treatment receiving biochar at 40 or $60 \mathrm{t} \cdot \mathrm{ha}^{-1}$ suggesting that there were significant differences in the carry over effect of biochar levels beyond $40 \mathrm{t} \cdot \mathrm{ha}^{-1}$.

\subsection{Cobs Weight $\left(\mathrm{kg} \cdot \mathrm{ha}^{-1}\right)$}

The data showed that cobs weight was considerably affected by cropping system, biochar level as well as by their interactive effect (Table 2). The cobs weight of maize was significantly greater for treatment following chickpea than wheat in the preceding period suggesting that the carry over effect of chickpea was more 
evident than wheat on the following maize crop (Figure 2). Similarly, the cobs weight was significantly greater for treatment receiving biochar in the previous season than in the control treatment. The results show that maximum cobs weight of $6881 \mathrm{~kg} \cdot \mathrm{ha}^{-1}$ was obtain with the appliance of biochar at $80 \mathrm{t} \cdot \mathrm{ha}^{-1}$, but it was statistically alike to treatments receiving biochar at 40 or $60 \mathrm{t} \cdot \mathrm{ha}^{-1}$. The lowest cobs weight was observed in the control treatment. These results suggested the strong carry over effect of biochar applied previously on the following maize. [20] reported that application of biochar at $5 \mathrm{t} \cdot \mathrm{ha}^{-1}$ plus $100 \%$ recommended dose of inorganic fertilizer plus biofertilizers produced the highest cobs weight $(310 \mathrm{~g})$ over all other treatments including control.

\subsection{Grain Yield (kg·ha-1)}

The grain yield of maize as affected by different level of biochar and cropping systems is shown in Table 3. Grain yield was considerably affected by cropping system (CS), biochar (BC) levels and by their interaction. Like the grain yield $\left(5261 \mathrm{~kg} \cdot \mathrm{ha}^{-1}\right)$ of maize was significantly greater for treatment under chickpea/maize than under the wheat/maize cropping system (Figure 3). Moreover, biochar exhibited tough carry over effect on grain yield of maize as the grain yield be considerably better in biochar than in the control treatments. Like biological yield, the highest grain yield of $5098 \mathrm{~kg} \cdot \mathrm{ha}^{-1}$ was obtain in the treatments received biochar at $40 \mathrm{t} \cdot \mathrm{ha}^{-1}$ while the lowest grain yield of $3685 \mathrm{~kg} \cdot \mathrm{ha}^{-1}$ was obtained in the control treatment. It was evident that the grain yield obtained in all biochar treatments was statistically similar or indifferent. [10] also reported that biochar. Application at the @ 20 and $30 \mathrm{t} \cdot \mathrm{ha}^{-1}$ appreciably improved the grains yield of maize. [21] found that grains yield was considerably improved with the application of biochar at $100 \mathrm{t} \cdot \mathrm{ha}^{-1}$. Our result is also supported by [22]. [23] who reported that appliance of biochar improved the yields of crops due to better

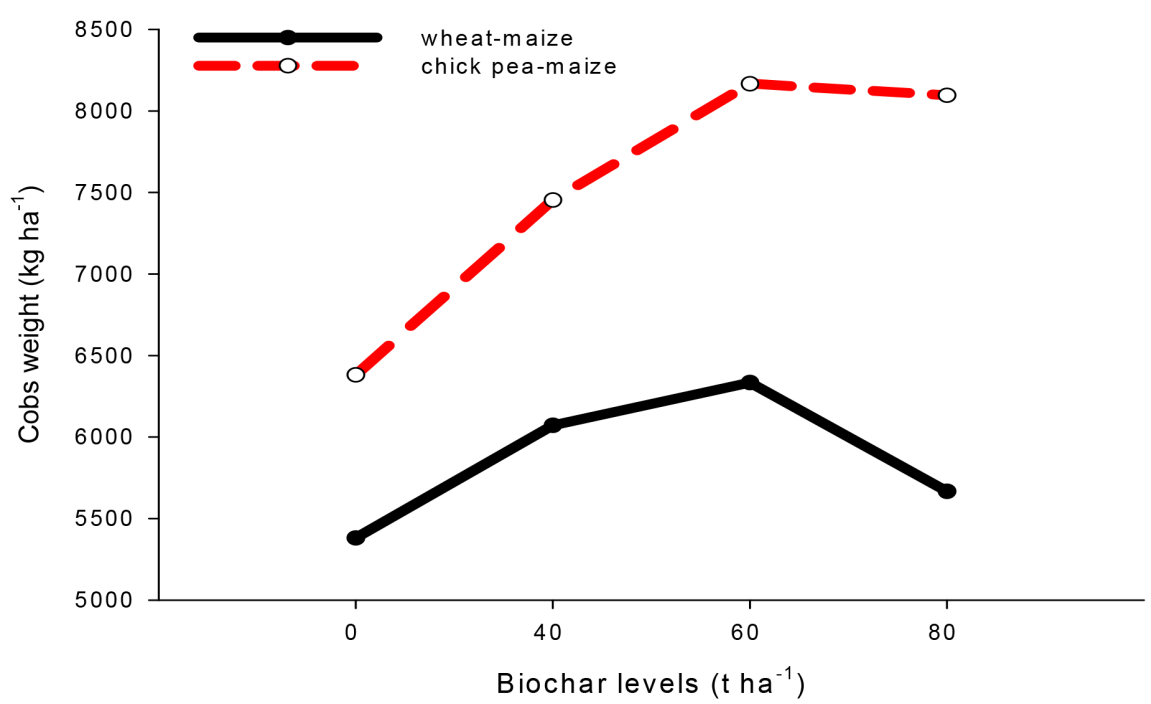

Figure 2. The influence of cropping systems and biochar interaction on cobs weight $\left(\mathrm{kg} \cdot \mathrm{ha}^{-1}\right)$ of maize. 


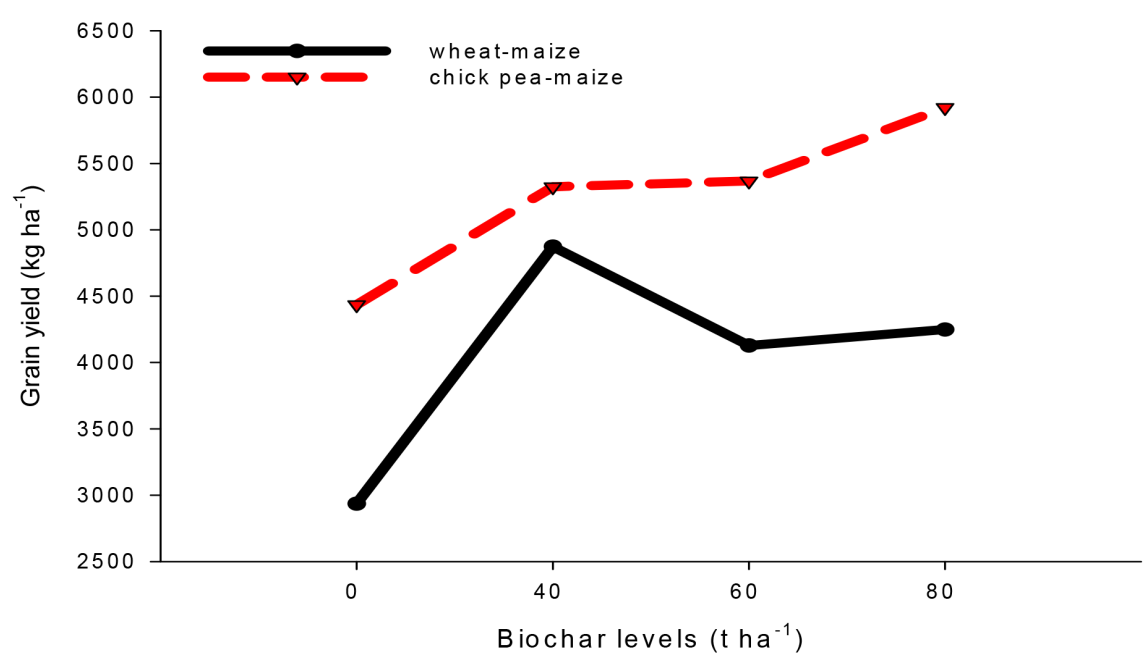

Figure 3. The influence of cropping systems and biochar interaction on grain yield $\left(\mathrm{kg} \cdot \mathrm{ha}^{-1}\right)$ of maize.

Table 3. Grain yield $\left(\mathrm{kg} \cdot \mathrm{ha}^{-1}\right)$, stover yield $\left(\mathrm{kg} \cdot \mathrm{ha}^{-1}\right)$ and harvest index (\%) of maize crop as affected by cropping systems and previous application biochar.

\begin{tabular}{cccc}
\hline Cropping system (CS) & Grain yield & Stover yield & Harvest index \\
\hline Wheat-maize & $4046 \mathrm{~b}$ & 9057 & 27 \\
Chickpea-maize & $5261 \mathrm{a}$ & 11,080 & 28 \\
Significance $(\mathrm{p} \leq 0.05)$ & $*$ & $\mathrm{NS}$ & $\mathrm{NS}$ \\
Biochar $(\mathrm{BC})\left(\mathrm{t} \cdot \mathrm{ha}^{-1}\right)$ & & & \\
0 & $3685 \mathrm{~b}$ & 9125 & 24 \\
40 & $5098 \mathrm{a}$ & 11,000 & 29 \\
60 & $4748 \mathrm{a}$ & 9417 & 28 \\
80 & $5084 \mathrm{a}$ & 10,732 & 28 \\
LSD value $(\mathrm{p} \leq 0.05)$ & 969 & NS & NS \\
Interaction & $*$ & & \\
CS $\times$ BC & $*$ & NS & NS \\
\hline
\end{tabular}

NS = non-significant

supply of water to plants. Our result are supported by [24] who also reported that maize yield was improved by the combined use of organic manures and mineral nitrogen. [19] reported that $5 \mathrm{t} \cdot \mathrm{ha}^{-1}$ biochar plus $100 \%$ recommended dose of inorganic fertilizer plus biofertilizer increased the grain and stover yield of 8100 and $12,150 \mathrm{~kg} \cdot \mathrm{ha}^{-1}$ of maize, respectively. [25] observed that the appliance of biochar at the @15 thha ${ }^{-1}$ produced maximum grain yield $\left(31 \mathrm{t} \cdot \mathrm{ha}^{-1}\right)$ of maize compared with $0.51 \mathrm{t} \cdot \mathrm{ha}^{-1}$ in the control plot. [19] reported that high grain yields of $4194 \mathrm{~kg} \cdot \mathrm{ha}^{-1}$ of maize was produced in treatment where biochar and chemical fertilizer were applied whereas lower grain yield of $2042 \mathrm{~kg} \cdot \mathrm{ha}^{-1}$ was noticed for control treatments. 


\subsection{Stover Yield $\left(\mathrm{kg} \cdot \mathrm{ha}^{-1}\right)$}

Data revealed that stover yield of maize was not significantly affected by biochar, cropping system or by their interactions (Table 3). Although the stover yields of maize was not considerably affected by cropping system yet greater stover yield was obtained for treatment having chickpea than wheat in the preceding season. In case of biochar, no significant affect on stover yield of maize was observed by any of the biochar level applied in the previous season compared with the control. It was however, observed that the maximum stover yield of $11,000 \mathrm{~kg} \cdot \mathrm{ha}^{-1}$ was obtained for the treatment receiving biochar at $40 \mathrm{t} \cdot \mathrm{ha}^{-1}$ but this was statistically at par with all other treatments including control. However [20] reported that biochar at $5 \mathrm{t} \cdot \mathrm{ha}^{-1}$ plus $100 \%$ recommended dose of inorganic fertilizers along with biofertilizer increased the stover yield of maize.

\subsection{Harvest Index (\%)}

The data showed that cropping systems, biochar levels and their interactions (CS $\times \mathrm{BC}$ ) had no significant effect on harvest index of maize (Table 3). However, somehow improved harvest index of $28.3 \%$ was observed for treatment following chickpea than wheat in previous season. Although statistical non-significant, harvest index of maize was generally greater for biochar than for the control treatment. The results showed that higher harvest index of $29.4 \%$ was recorded for treatment receiving biochar (BC) at $40 \mathrm{t} \cdot \mathrm{ha}^{-1}$ while the lowest harvest index of $24.1 \%$ was recorded for the control treatment. [26] [27] found that application of biochar improved harvest index. [28] reported that higher biochar application produced significantly $(\mathrm{p}<0.05)$ higher $\mathrm{HI}$ values in each year $(0.44$ in 2003 , 0.47 in 2004 and 0.50 in 2005).

\subsection{Nitrogen Concentration in Grain (\%)}

The data showed that nitrogen concentration in grains was not considerably effected by cropping systems and biochar levels (Table 4). Although significantly non different, the maximum nitrogen concentration of $1.58 \%$ was obtained in the treatment under wheat-maize cropping system which was statistically similar to that under chickpea-maize cropping system (Figure 4). The effect of biochar levels was not significant yet the maximum nitrogen concentration of $1.61 \%$ in maize grains was observed with the application of biochar at $60 \mathrm{t} \cdot \mathrm{ha}^{-1}$ which was similar to all other treatments including the control. [28] reported that $\mathrm{N}$ concentration in maize grains increased with application of biochar. Alike result have also been reported by [29]. In another study, it was also found that nitrogen concentration was increased with the application of biochar [30].

\subsection{Nitrogen Concentration in Stover (\%)}

The data showing nitrogen concentration in stover of maize as affected by cropping system and biochar levels are presented in Table 4 . The nitrogen concentrations was non-significantly affected by cropping systems yet the maximum 
Table 4. Nitrogen concentration in grains and stover (\%) and total $\mathrm{N}$ uptake $\left(\mathrm{kg}^{\mathrm{h}} \cdot \mathrm{ha}^{-1}\right)$ of maize as affected by cropping systems and previous application biochar.

\begin{tabular}{|c|c|c|c|}
\hline Cropping system(CS) & $\mathrm{N}$ conc. in grains & $\mathrm{N}$ conc. in stover & Total $\mathrm{N}$ uptake \\
\hline Wheat-maize & 1.58 & 0.75 & $132 b$ \\
\hline Chickpea-maize & 1.49 & 0.86 & $174 a$ \\
\hline Significance $(\mathrm{P} \leq 0.05)$ & NS & NS & * \\
\hline \multicolumn{4}{|l|}{ Biocahar (BC) $\left(\mathrm{t} \cdot \mathrm{ha}^{-1}\right)$} \\
\hline 0 & 1.50 & $0.72 b$ & $118 \mathrm{c}$ \\
\hline 40 & 1.43 & $0.83 \mathrm{ab}$ & $165 \mathrm{ab}$ \\
\hline 60 & 1.61 & $0.69 \mathrm{~b}$ & $143 \mathrm{bc}$ \\
\hline 80 & 1.60 & $0.98 \mathrm{a}$ & $187 \mathrm{a}$ \\
\hline $\operatorname{LSD}(P \leq 0.05)$ & NS & 0.23 & 38 \\
\hline \multicolumn{4}{|l|}{ Interaction } \\
\hline $\mathrm{CS} \times \mathrm{BC}$ & * & NS & * \\
\hline
\end{tabular}

NS = non-significant.

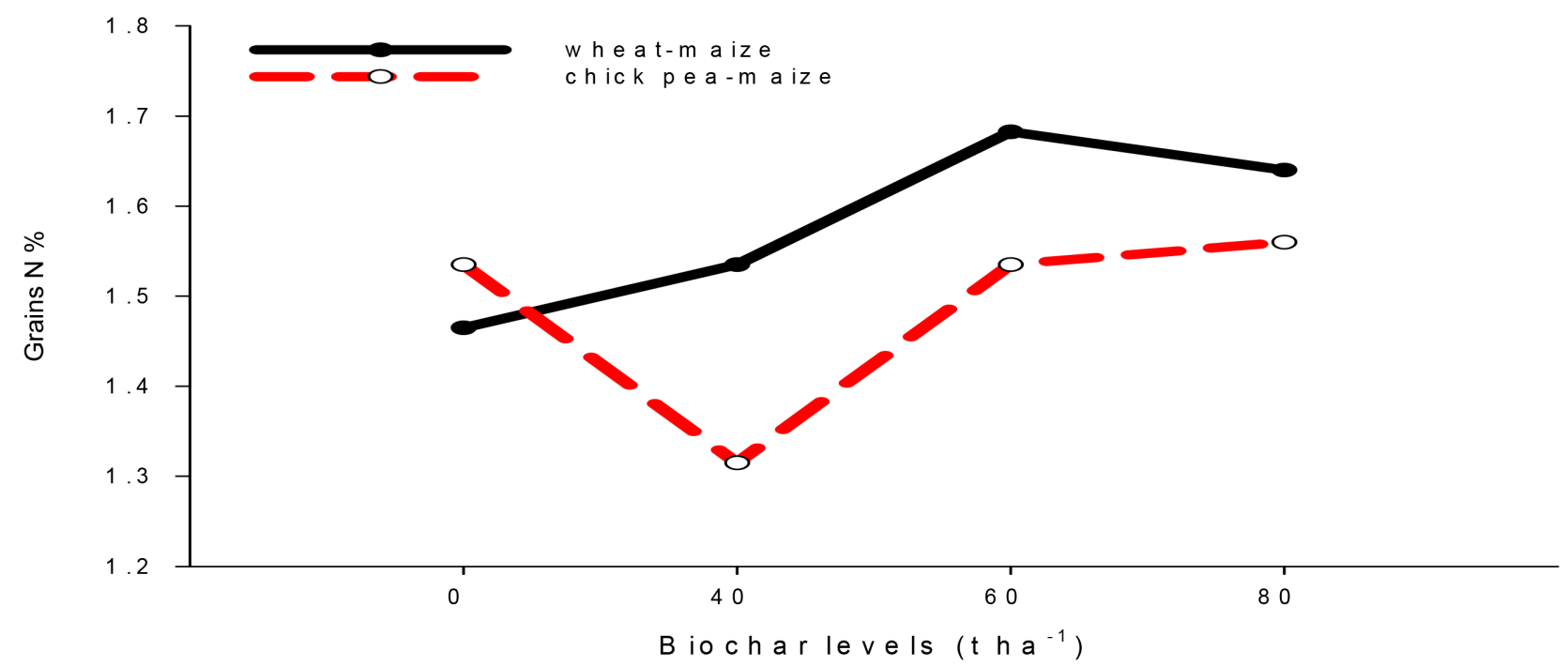

Figure 4. The influence of cropping systems and biochar interaction on grains $\mathrm{N}(\%)$ of maize.

concentration of $0.86 \%$ was observed in treatment following chickpea than wheat in the previous season Significantly greater nitrogen concentration of $0.98 \%$ in maize stover was obtained for treatment receiving biochar at $80 \mathrm{t} \cdot \mathrm{ha}^{-1}$ in the previous season and this was statistically at par with $0.83 \%$ noticed for treatments receiving biochar $40 \mathrm{t} \cdot \mathrm{ha}^{-1}$. furthermore, the differences in $\mathrm{N}$ concentration in stover between treatment receiving biochar at 40 or $60 \mathrm{t} \cdot \mathrm{ha}^{-1}$ and control treatments were statistically non-significant $(\mathrm{p} \leq 0.05)$ (Figure 5$)$. Contrary to our results, [28] observed that nitrogen concentration increased with the appliance of biochar at the @20 th ha ${ }^{-1}$. Alike result have also been reported by [29] who found that with the application of biochar nitrogen concentration increased which has the ability to increased nitrogen efficiency of nitrogen used. 


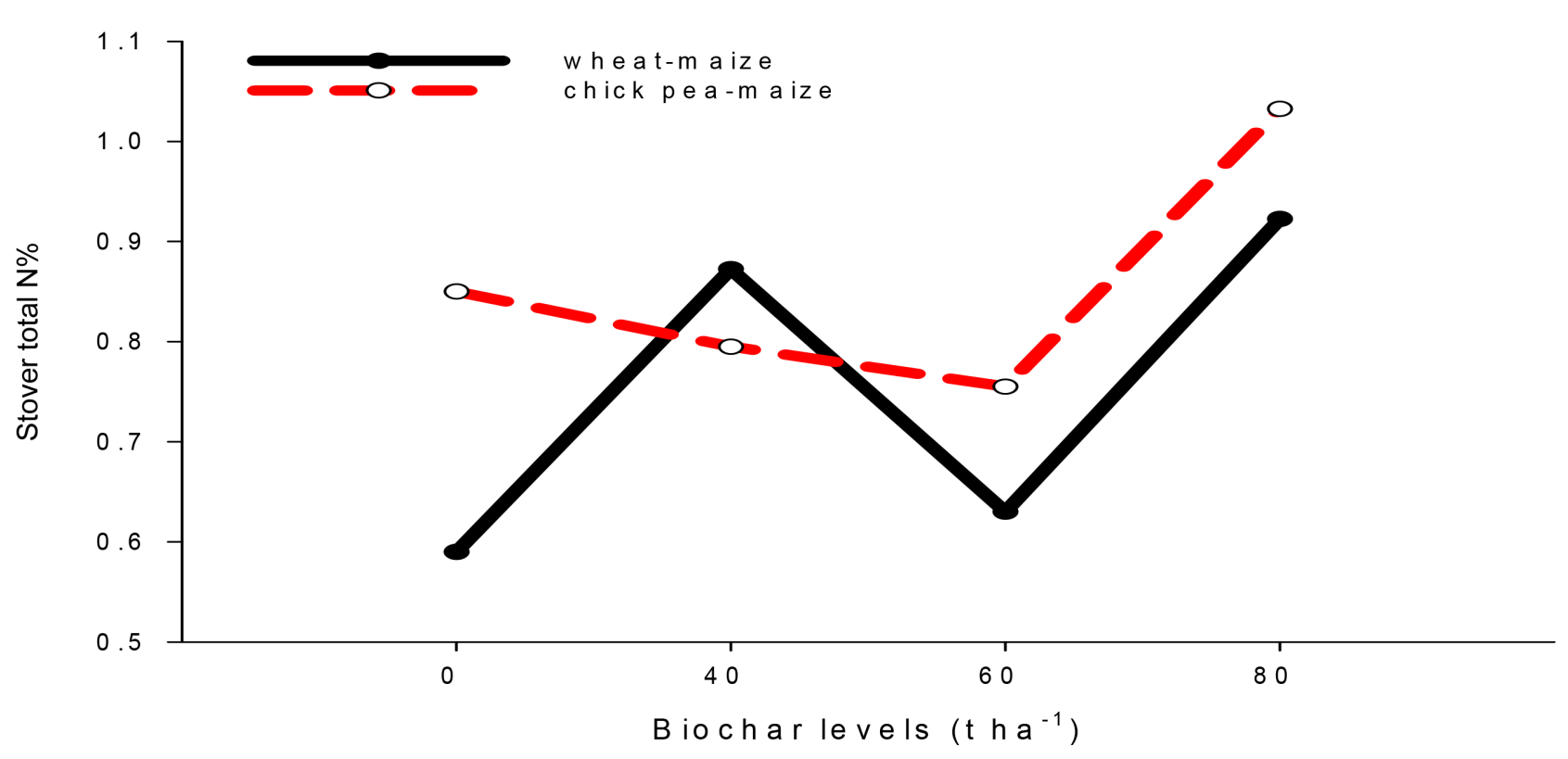

Figure 5. The influence of cropping systems and biochar interaction on stover N (\%) of maize.

\subsection{Total $\mathrm{N}$ Uptake $\left(\mathrm{kg} \cdot \mathrm{ha}^{-1}\right)$}

Data revealed that nitrogen uptake in maize was considerably affected by cropping systems and biochar levels and by their interaction (Table 4). Nitrogen uptake in maize was considerably better for treatments following chickpea than wheat in the previous season (Figure 6). These results suggest that chickpea had significant effect on $\mathrm{N}$ uptake in the following maize than wheat. Moreover, the $\mathrm{N}$ uptake in maize was significantly greater for treatment receiving biochar in the previous season than in the control. It was observed that the maximum $\mathrm{N}$ uptake of $187 \mathrm{~kg} \cdot \mathrm{ha}^{-1}$ was noticed for treatments having biochar at $80 \mathrm{t} \cdot \mathrm{ha}^{-1}$ followed by 60 and $40 \mathrm{t} \cdot \mathrm{ha}^{-1}$. While the lowest was observed in the control treatment, the results suggest the carry over effect of biochar applied previously. Our results are supported by [28] who report that appliance of biochar at the @ $20 \mathrm{t} \cdot \mathrm{ha}^{-1}$ significantly improved nitrogen uptake in maize plant. [29] also demonstrated that nitrogen uptake was significantly increased with the appliance of biochar. [31] reported that nitrogen uptake was significantly improved in biochar and sewage sludge amended treatments compare to the un amended control treatment.

\subsection{Soil Organic Carbon (\%)}

The data showed that soil organic carbon was significantly affected by cropping system and biochar levels (Table 5). The maximum soil organic carbon of $0.91 \%$ was noticed in the chickpea-maize cropping system follow by that in the chickpea-mung bean, wheat-maize and wheat-mung bean cropping system respectively. It was observed that soil organic carbon was generally larger for the treatments following chickpea than wheat in the preceding season. The soil organic carbon was also considerably better in the biochar than in the control treatments. The maximum organic carbon of $0.99 \%$ was noticed for the 


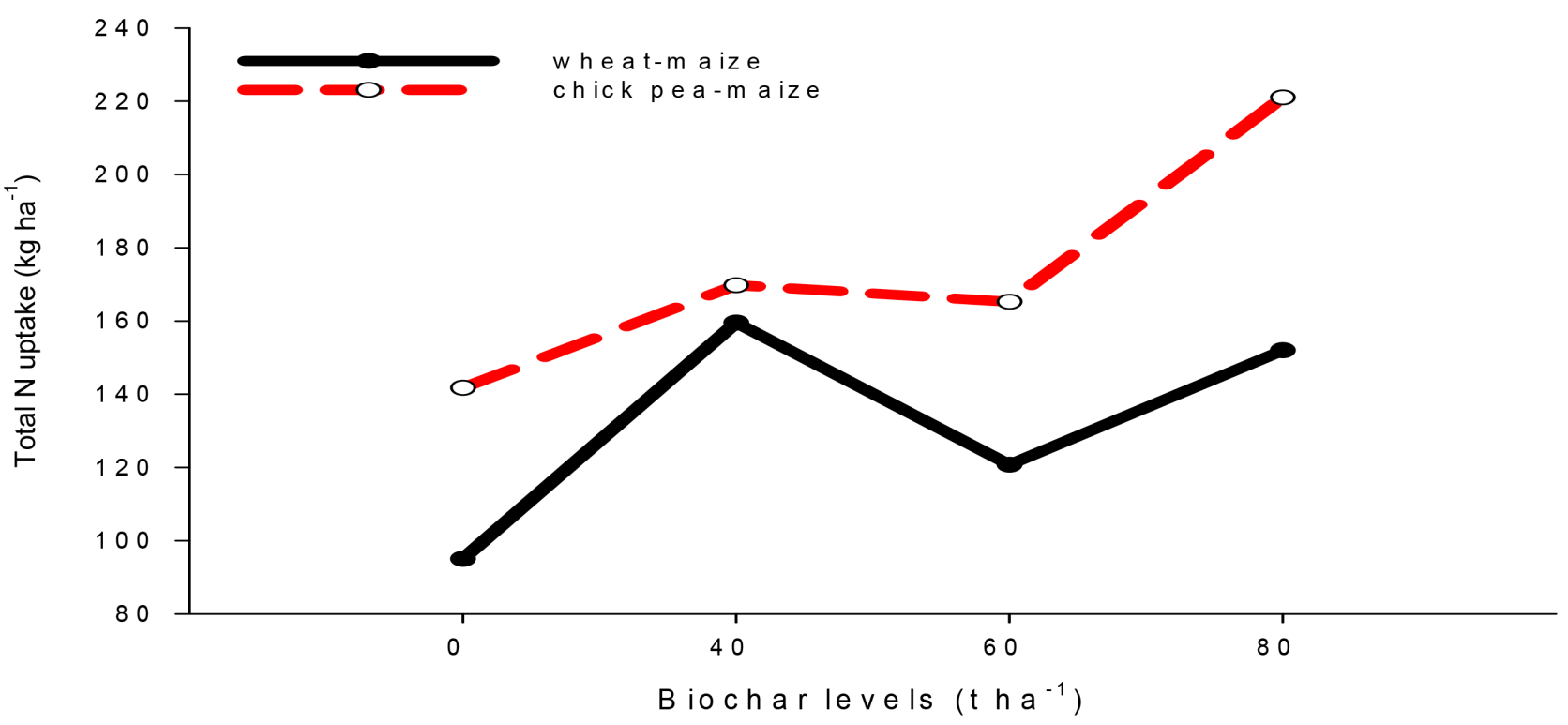

Figure 6. The influence of cropping systems and biochar interaction on total nitrogen uptake $\left(\mathrm{kg} \cdot \mathrm{ha}^{-1}\right)$ of maize.

Table 5. Soil organic carbon (\%), bulk density $\left(\mathrm{g} \cdot \mathrm{cm}^{-3}\right)$, and soil mineral $\mathrm{N}\left(\mathrm{ug} \cdot \mathrm{g}^{-1}\right)$ as affected by cropping systems and previous application biochar.

\begin{tabular}{|c|c|c|c|}
\hline Cropping system (CS) & Organic C & Bulk density & Mineral N \\
\hline Wheat-mung bean & $0.68 b$ & $1.52 \mathrm{ab}$ & 25.65 \\
\hline Wheat-maize & $0.71 \mathrm{~b}$ & $1.53 \mathrm{a}$ & 21.74 \\
\hline Chickpea-maize & $0.90 \mathrm{a}$ & $1.44 \mathrm{ab}$ & 11.55 \\
\hline Chickpea-mung bean & $0.83 \mathrm{ab}$ & $1.43 \mathrm{~b}$ & 9.74 \\
\hline Significance $(\mathrm{P} \leq 0.05)$ & * & * & NS \\
\hline \multicolumn{4}{|l|}{ Biochar (BC) $\left(\mathrm{t} \cdot \mathrm{ha}^{-1}\right)$} \\
\hline 0 & $0.63 c$ & $1.58 \mathrm{a}$ & $14.98 \mathrm{~b}$ \\
\hline 40 & $0.69 \mathrm{c}$ & $1.51 \mathrm{ab}$ & $17.65 \mathrm{ab}$ \\
\hline 60 & $0.82 b$ & $1.47 \mathrm{~b}$ & $20.46 a$ \\
\hline 80 & $0.9 \mathrm{a}$ & $1.35 \mathrm{c}$ & $15.59 \mathrm{ab}$ \\
\hline $\operatorname{LSD}(P \leq 0.05)$ & 0.07 & 0.09 & 5.28 \\
\hline \multicolumn{4}{|l|}{ Interactions } \\
\hline $\mathrm{CS} \times \mathrm{BC}$ & NS & * & * \\
\hline
\end{tabular}

NS = non-significant.

treatments having biochar at the rate of $80 \mathrm{t} \cdot \mathrm{ha}^{-1}$ followed by $0.82 \%$ for the treatment receiving biochar at $60 \mathrm{t} \cdot \mathrm{ha}^{-1}$. The lowest organic carbon of $0.64 \%$ was observed in the control treatment. These results showed the strong carry over effect of biochar receiving in the previous season. [32] observed that the application of biochar considerably increased SOC and $\mathrm{N}$ but decrease BD of the soil. [33] also found that total soluble $\mathrm{N}$, soluble $\mathrm{C}$, available $\mathrm{P}$, sodium, bulk density and exchangeable calcium were considerably improved with the application of 
biochar. [34] reported improved in SC with the application of biochar. Our results are also supported by [35] [36].

\subsection{Bulk Density $\left(\mathrm{g} \cdot \mathrm{cm}^{-3}\right)$}

The data showed that soil bulk density was considerably affected by cropping systems, biochar level as well as by their interactive effect (Table 5). The lowest bulk density of soil $1.43 \mathrm{~g} \cdot \mathrm{cm}^{-3}$ was obtained for treatment under chickpea-mung bean cropping, whereas the greater bulk density $\left(1.52 \mathrm{~g} \cdot \mathrm{cm}^{-3}\right)$ for treatment under wheat-maize cropping system (Figure 7). These results suggest that legumes cropping significantly reduced the bulk density of soil compared with continuous cereal-cereal cropping system. The soil BD was also considerably lower in the biochar than in the control treatments. The minimum bulk density of $1.3538 \mathrm{~g} \cdot \mathrm{cm}^{-3}$ was obtained for the treatment receiving biochar at the @80 $\mathrm{t} \cdot \mathrm{a}^{-1}$ followed by $1.4719 \mathrm{~g} \cdot \mathrm{cm}^{-3}$ for the treatments having biochar at $60 \mathrm{t} \cdot \mathrm{ha}^{-1}$. The greater bulk density was recorded in the control treatments. These results suggest the strong carry over influence of biochar applied previously on the soil bulk density. [37] reported that rising total organic carbon by the accumulation of organic amendments in soils could extensively drop off bulk density. Moreover, the decrease in bulk density of the biochar-amended soils appears to have also been the result of modification of soil aggregate sizes, as shown by [38]. Physical properties of soil such as texture, porosity, $\mathrm{BD}$, soil structure and particle size distribution can also be improved with the application of biochar [39]. Similar result have also been report by [40] as well as [41] who found that bulk density, porosity and water holding capacity were improved with the application of biochar.

\subsection{Soil Mineral N (ug·g-1 Soil)}

The data showed that soil mineral nitrogen was not significantly affected by cropping systems but it was significantly affected with the application of biochar (Table 5). The interaction effect was also significant (Figure 8). The highest soil mineral nitrogen (20.46 ug. $\mathrm{g}^{-1}$ soil) was noticed for the treatments having biochar at $60 \mathrm{t} \cdot \mathrm{ha}^{-1}$. The results were however, inconsistent as no considerable differences in soil mineral nitrogen were obtained among the control treatment and the treatment receiving highest level of biochar (i.e. $80 \mathrm{t} \cdot \mathrm{ha}^{-1}$ ). Microbial $\mathrm{N}$ immobilization cause if organic matter with higher $\mathrm{C} / \mathrm{N}$ ratio (more than 1:20) is applied to the soil [42]. [43] viewed that there is some component in biochar which cause $\mathrm{N}$ immobilization.

\subsection{3. $\mathrm{pH}$ of the Soil}

The data showed that soil $\mathrm{pH}$ was not significantly affected by cropping systems but it was significantly affected with the application of biochar (Table 6). Highest soil $\mathrm{pH}$ (7.91) was observed for the treatment having biochar at $60 \mathrm{t} \cdot \mathrm{ha}^{-1}$. The result were however, inconsistent as no significant differences in soil $\mathrm{pH}$ were 


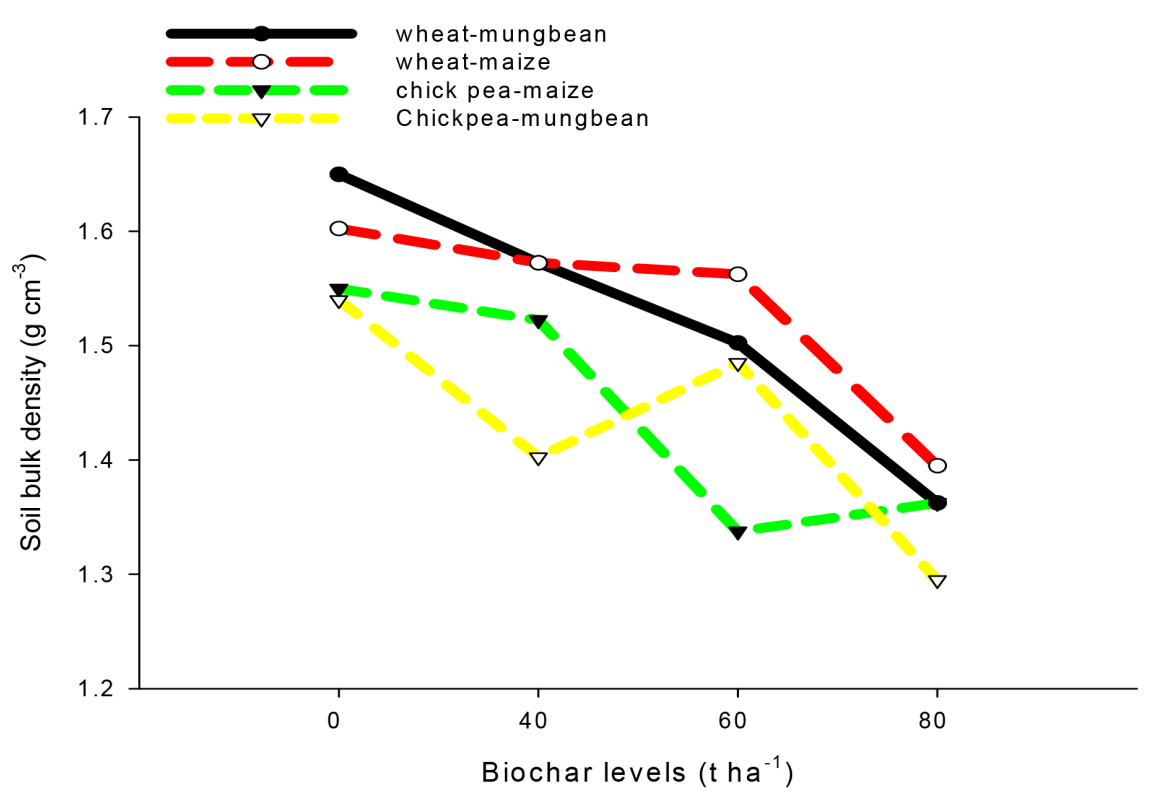

Figure 7. The influence of cropping systems and biochar interaction on soil bulk density $\left(\mathrm{g} \cdot \mathrm{cm}^{-3}\right)$.

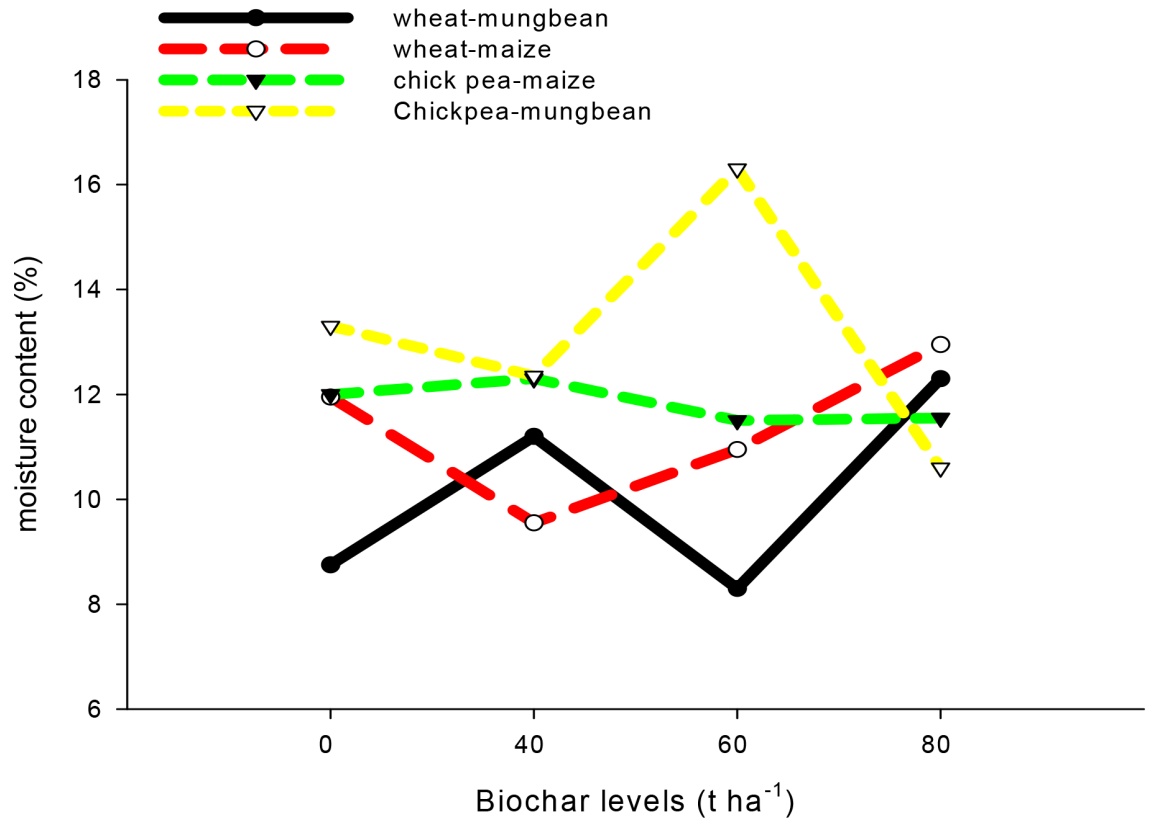

Figure 8. The influence of cropping systems and biochar interaction on mineral nitrogen $\left(\right.$ ug. g $\left.^{-1}\right)$.

observed between the control treatment and treatment receiving the highest level of biochar $\left(\right.$ i.e. $\left.80 \mathrm{t} \cdot \mathrm{ha}^{-1}\right)$. Our results are generally contrary to the published literature. For example, [44] reported that biochar application significantly enhanced $\mathrm{pH}$ of the soil. [45] also reported that in highly weathered soil, $\mathrm{pH}$, base saturation and CSC were significantly increased with the application of biochar. [33] also reported similar results. 
Table 6. Soil $\mathrm{pH}$, electrical conductivity $\left(\mathrm{dS} \cdot \mathrm{m}^{-1}\right)$ and moisture content (\%) as affected by cropping systems and previous application of biochar.

\begin{tabular}{ccc}
\hline Cropping system $(\mathrm{CS})$ & $\mathrm{pH}$ & $\mathrm{ECe}$ \\
\hline Wheat-mung bean & 7.88 & 0.12 \\
Wheat-maize & 7.87 & 0.12 \\
Chickpea-maize & 7.92 & 0.14 \\
Chickpea-mung bean & 7.88 & 0.13 \\
Significance $(\mathrm{P} \leq 0.05)$ & $\mathrm{NS}$ & $\mathrm{NS}$ \\
Biochar $(\mathrm{BC})\left(\mathrm{t} \cdot \mathrm{ha}^{-1}\right)$ & & \\
0 & $7.89 \mathrm{ab}$ & 0.13 \\
40 & $7.89 \mathrm{ab}$ & 0.12 \\
60 & $7.91 \mathrm{a}$ & 0.14 \\
80 & $7.86 \mathrm{~b}$ & 0.12 \\
LSD $(\mathrm{P} \leq 0.05)$ & 0.043 & $\mathrm{NS}$ \\
Interactions & & $\mathrm{NS}$ \\
$\mathrm{CS} \times \mathrm{BC}$ & $\mathrm{NS}$ &
\end{tabular}

NS =non-significant

\subsection{Soil ECe $\left(d S \cdot m^{-1}\right)$}

Data showed that soil ECe was non-significantly affected by cropping system, biochar levels and by their interactions (Table 6). Although significantly non different, the highest soil ECe of $0.149 \mathrm{dS} \cdot \mathrm{m}^{-1}$ was obtained for the treatment following chickpea-maize cropping system which was statistically similar to other treatments following other cropping systems. Similarly, differences in soil ECe between the biochar levels and control treatments were statistically non-significant. However, the highest ECe of $0.141 \mathrm{dS} \cdot \mathrm{m}^{-1}$ was observed with the application of biochar at $60 \mathrm{t} \cdot \mathrm{ha}^{-1}$ which was statistically similar to all other treatments including control. Published literature showed that the ECe of the soil generally increased with the application of biochar due to release of weakly bond nutrients (cations and anions) of biochar into the soil solution, which are accessible for uptake of plant. [43] [46] [47] reported that highest mean values of $\mathrm{pH}$ and EC were observed in soils treated with $10 \mathrm{t} \cdot \mathrm{ha}^{-1}$ biochar.

\section{Conclusion and Recommendations}

It could be concluded from the results of this study that the chickpea-maize cropping system performed better in terms of improving yield and yield components of maize, and in improving various soil properties. Application of biochar also improved various yield and yield components of maize and soil properties. It is therefore recommended that legumes must be involved in cropping system for sustainable and higher crop productivity and improved soil proper- 
ties. However further studies are suggested to find out suitable dose of biochar for sustainable and economic crop productivity and soil fertility.

\section{References}

[1] Khaliq, T., Mahmood, T. and Masood, A. (2004) Effectiveness of Farm Yard Manure, Poultry Manure and Nitrogen for Corn Productivity. International Journal of Agriculture and Biology, 2, 260-263.

[2] Iqbal, A., Amanullah, A. and Iqbal. M. (2015) Impact of Potassium Rates and Their Application Time on Dry Matter Partitioning, Biomass and Harvest Index of Maize (Zea mays) with and without Cattle Dung Application. Emirates Journal of Food and Agriculture, 27, 447-453. https://doi.org/10.9755/ejfa.2015.04.042

[3] Ministry of National Food Security \& Research (2014) Agricultural Statistics of Pakistan. Government of Pakistan, Ministry of National Food Security and Research, Division (Economic Wing), Islamabad.

[4] Lehmann, J., da Silva Jr., J.P. Rondon, M., Nehls, T., Zech, W. and Glaser, B. (2006) Nutrient Availability and Leaching in an Archaeological Anthrosol and a Ferralsol of the Central Amazon Basin: Fertilizer, Manure and Charcoal Amendments. Plant \& Soil, 249, 343-357. https://doi.org/10.1023/A:1022833116184

[5] Glaser, B., Lehmann, J. and Zech, W. (2002) Ameliorating Physical and Chemical Properties of Highly Weathered Soils in the Tropics with Charcoal: A Review. Biology and Fertility of Soils, 35, 219-230. https://doi.org/10.1007/s00374-002-0466-4

[6] Yuan, J.-H., Xu, R.-K. and Zhang, H. (2011) The Forms of Alkalis in the Biochar Produced from Crop Residues at Different Temperatures. Bioresource Technology, 102, 3488-3497. https://doi.org/10.1016/j.biortech.2010.11.018

[7] Verheijen, F., Jeffery, S., Bastos, A.C., Velde, M.V.D. and Diafas, I. (2004) A Critical Scientific Review of Effects on Soil Properties, Processes and Functions. Office for Official Publications of the European Communities, Luxembourg.

[8] Lehmann, J. (2007) Bio-Energy in the Black. Frontiers in Ecology and the Environment, 5, 381-387. https://doi.org/10.1890/1540-9295(2007)5[381:BITB]2.0.CO;2

[9] Steiner, C., Teixeira, W.G., Lehmann, J., Nehls, T., de MacêDo, J.L.V., Blum, W.E.H. and Zech, W. (2007) Long Term Effects of Manure, Charcoal and Mineral Fertilization on Crop Production and Fertility on a Highly Weathered Central Amazonian Upland Soil. Plant and Soil, 291, 275-290.

https://doi.org/10.1007/s11104-007-9193-9

[10] Uzoma, K.C., Inoue, M., Andry, H., Fujimaki, H., Zahoor, A. and Nihihara, E. (2011) Effect of Cow Manure Biochar on Maize Productivity under Sandy Soil Condition. Soil Use and Management, 27, 205-212. https://doi.org/10.1111/j.1475-2743.2011.00340.x

[11] Chan, K., Van Zwieten, Y.L., Meszaros, I., Downie, A. and Joseph, S. (2007) Using Poultry Litter Biochars as Soil Amendments. Australian Journal of Soil Research, 46, 437-444. https://doi.org/10.1071/SR08036

[12] Steel, R.G.D. and Terrie, J.H. (1996) Principles and Procedures of Statistics: A Biometrical Approach. 2nd Edition, McGraw-Hill, New York.

[13] Blake, G.R and Hartage, K.H. (1984) Bulk Density. In: Campbell, G.S., Jackson, R.D., Mart, M.M., Nilson, D.R. and Klute, A., Eds., Methods of Soil Analysis, Part 1, American Society of Agronomy, Inc., Madison, WI, 364-366.

[14] Nelson, D.W and Sommer, L.E. (1996) Total Carbon, Organic Carbon, and Organic Matter. In: Spark, D.L., Ed., Method of Soil Analysis, Part 3, American Society of 
Agronomy, Vol. 34, 961-1010.

[15] Bremner, J.M. and Mulvaney, C.S. (1996) Kjeldhal Method. In: Method of Soil Analysis Part 2: Chemical \& Microbiological Properties, American Society of Agronomy, Madison, 903-948.

[16] McClean, E.O. (1982) Soil pH and Lime Requirement. In: Page, A.L., Miller, R.H. and Keeny, D.R., Eds., Methods of Soil Analysis, 22nd Edition, American Society of Agronomy, Madison, Vol. 9, 199-208, 209-223.

[17] Bremner, J.M. (1996) Nitrogen Total. In: Sparks, D.L., Ed., Methods of Soil Analysis, Part 3, American Society of Agronomy, Madison, Vol. 37, 1085-1022.

[18] Glaser, B., Lehmann, J. and Zech, W. (2002) Ameliorating Physical and Chemical Properties of Highly Weathered Soils in the Tropics with Charcoal: A Review. Biology and Fertility of Soils, 35, 219-230. https://doi.org/10.1007/s00374-002-0466-4

[19] Arif, M., Ali, K., Munsif, F., Ahmad, W., Ahmad, A. and Naveed, K. (2012) Effect of Biochar, FYM and Nitrogen on Weeds Andmaize Phenology. Pakistan Journal of Weed Science Research, 18, 475-484.

[20] Gokila, B. and Baskar, K. (2015) Influence of Biochar as a Soil Amendment on Yield and Quality of Maize in Alfiosl of Thoothukudi District of Tamilnadu, India. International Journal of Plant, Animal and Environmental Sciences, 5, 2231-4490.

[21] Solaiman, Z.M., Blackwell, P., Abbott, L.K. and Storer, P. (2010) Direct and Residual Effect of Biochar Application on Mycorrhizal Root Colonisation, Growth and Nutrition of Wheat. Australian Journal of Soil Research, 48, 546-554. https://doi.org/10.1071/SR10002

[22] Antonio, J.A., Salazar, P., Barrón, V., Torrent, J., María, D., Campillo, C., Gallardo, A. and Villar, R. (2013) Enhanced Wheat Yield by Biochar Addition under Different Mineral Fertilization Levels. Agronomy for Sustainable Development, 33, 475-484. https://doi.org/10.1007/s13593-012-0128-3

[23] Blackwell, P., Krull, E., Butler, G., Herbert, A. and Solaiman, Z. (2010) Effect of Banded Biochar on Dryland Wheat Production and Fertilizer Use in South-Western Australia an Agronomic and Economic Perspective. Australian Journal of Soil Research, 48, 531-545. https://doi.org/10.1071/SR10014

[24] Singh, B., Singh, B.P. and Cowie, A.L. (2010) Characterisation and Evaluation of Biocharfortheir Application as a Soil Amendment. Australian Journal of Soil Research, 48, 516-525. https://doi.org/10.1071/SR10058

[25] Njoku, C., Mbah, C.N., Igboji, P.O., Nwite, J.N., Chibuike, C.C. and Uguru, B.N. (2015) Effect of Biochar on Selected Soil Physical Properties and Maize Yield in an Ultisol in Abakaliki Southeastern Nigeria. Global Advanced Research Journal of Agricultural Science, 4, 864-870.

[26] Wang, T., Arbestain, C., Hedley, M. and Bishop, M. (2012) Chemical and Bioassay Characterisation of Nitrogen Availability in Biochar Produced from Dairy Manure and Biosolids. Organic Geochemistry, 51, 45-54. https://doi.org/10.1016/j.orggeochem.2012.07.009

[27] Carter, S., Shackley, S., Sohi, S., Suy, T.B. and Haefele, S. (2013) The Impact of Bacillus Species on Growth and Yield of French Beans. Scientia Horticulturae, 162, 351-356.

[28] Major, J., Rondon, M., Molina, D., Susan, J.R. and Lehmann, J. (2010) Maize Yield and Nutrition during 4 Years after Biochar Application to a Colombian Savanna Oxisol. Plant Soil, 333, 117-128. https://doi.org/10.1007/s11104-010-0327-0

[29] DeLuca, T.H., MacKenzie, M.D. and Gundale, M.J. (2009) Biochar Effects on Soil 
Nutrient Transformations. In: Lehmann, J. and Joseph, S., Eds., Biochar for Environmental Management Science and Technology, Earthscan, London, 251-270.

[30] Chan, K., Van Zwieten, Y.L., Meszaros, I., Downie, A. and Joseph, S. (2007) Using Poultry Litter Biochars as Soil Amendments. Australian Journal of Soil Research, 46, 437-444. https://doi.org/10.1071/SR08036

[31] Gwenzi, W., Muzava, M., Mapanda, F. and Tauro, T.P. (2015) Comparative Short-Term Effects of Sewage Sludge and Its Biochar on Soil Properties, Maize Growth and Uptake of Nutrients on a Tropical Clay Soil in Zimbabwe. Journal of Integrative Agriculture, 15, 1395-1406. https://doi.org/10.1016/S2095-3119(15)61154-6

[32] Zhang, A., Cui, L., Pan, G., Li, L., Hussain, Q., Zhang, X., Zheng, J. and Crowley, D. (2010) Effect of Biochar Amendment on Yield and Methane and Nitrous Oxide Emissions from a Rice Paddy from Tailake Plain, China. Agriculture, Ecosystems \& Environment, 139, 469-475.

[33] Jones, D.L., Rousk, J., Edwards, J.G., DeLuca, T.H. and Murphy, D.V. (2011) Biochar-Mediated Changes in Soil Qualityand Plant Growth in a Three Year Field Trial. Environment Centre Wales, Bangor.

[34] Rackham, O. (1980) Ancient Woodland: Its History, Vegetation and Uses in England. E. Arnold Press, London.

[35] Kookana, R.S., Sarmah, A.K., Zwieten, V.L., Krull, E. and Singh, B. (2011) Biochar Application to Soilagronomic and Environmental Benefits and Unintended Consequences. Advances in Agronomy, 112, 103-143. https://doi.org/10.1016/B978-0-12-385538-1.00003-2

[36] Boateng, S.A., Zickermann, J. and Kornaharens, M. (2006) Effect of Poultry Manure on Growth and Yield of Maize. West African Journal of Applied Ecology, 9, 150-1579.

[37] Busscher, W., Novak, J.M. and Ahmedna, M. (2011) Physical Effects of Organic Matter Amendment of a Southeastern US Coastal Loamy Sand. Soil Science, 176, 661-667.

[38] Timalsina, R., Bishwoyog, A., Neupane, J., Dhakal, S.P., Nepal, J., Gnyawali, B., Timalsina, R. and Poudel, A. (2015) Eeffect of Biochar from Different Origin on Physio-Chemical Properties of Soil and Yield of Garden Pea (Pisumsativum L.) at Paklihawa, Rupandehi, Nepal. World Journal of Agricultural Research, 3, 129-138.

[39] Antonio, J.A., Salazar, P., Barrón, V., Torrent, J., María, D., Campillo, C., Gallardoand, A. and Villar, R. (2013) Enhanced Wheat Yield by Biochar Addition under Different Mineral Fertilization Levels. Agronomy for Sustainable Development, 33, 475-484. https://doi.org/10.1007/s13593-012-0128-3

[40] Asai, H., Samson, K.B., Stephan, M.H., Songyir, K., Homma, K. and Kiyono, Y. (2009) Biochar Amendment Techniques for Upland Rice Production in Northern Laos 1. Soil Physical Properties, Leaf SPAD and Grain Yield. Field Crops Research, 111, 81-84. https://doi.org/10.1016/j.fcr.2008.10.008

[41] Laird, D.A., Fleming, P., Davis, D., Horton, R., Wary, B. and Karien, D. (2010) Impact of Biochar Amendments on the Quality of Typical Mid-Western Agricultural Soil. Geoderma, 158, 443-449. https://doi.org/10.1016/j.geoderma.2010.05.013

[42] Fisher, R.F. and Benklay, D. (2000) Ecology and Management of Forest Soils. John Willey and Sons, New York, 321.

[43] Gundale, M.J. and DeLuca, T.H. (2007) Charcoal Effect on Soil Solution and Growth of Koeleriamacrantha and the Ponderosa Pine/Douglas-Fir Ecosystem. Bio 
Fertilizer of Soils, 43, 303-311.

[44] Yuan, J.-H., Xu, R.-K. and Zhang, H. (2011) The Forms of Alkalis in the Biochar Produced from Crop Residues at Different Temperatures. Bioresource Technology, 102, 3488-3497. https://doi.org/10.1016/j.biortech.2010.11.018

[45] Wang, T., Arbestain, C., Hedley, M. and Bishop, M. (2012) Chemical and Bioassay Characterisation of Nitrogen Availability in Biochar Produced from Dairy Manure and Biosolids. Organic Geochemistry, 51, 45-54. https://doi.org/10.1016/j.orggeochem.2012.07.009

[46] Glaser, B., Balashov, E., Haumaier, L., Guggenbergeran, G. and Zech, W. (2000) Black Carbon in Densityfractions of Anthropogenic Soils of the Brazilian Amazon Region. Organic Geochemistry, 31, 669-678. https://doi.org/10.1016/S0146-6380(00)00044-9

[47] Nigussie, A., Kissi, E., Misganaw, M. and Ambaw, G. (2012) Effect of Biochar Application on Soil Properties and Nutrient Uptake of Lettuces (Lactucasativa) Grown in Chromium Polluted Soils. American-Eurasian Journal of Agricultural \& Environmental Sciences, 12, 369-376. 